\title{
BMJ Open HIV-1 disease progression in immune- competent HIV-1-infected and breastfeeding mothers participating in the ANRS 12174 clinical trial in Burkina Faso, South Africa, Uganda and Zambia: a cohort study
}

Eric Nagaonle Somé, ${ }^{1,2}$ Ingunn M S Engebretsen, ${ }^{1}$ Nicolas Nagot, ${ }^{3}$ Nicolas Yelbomkan Meda, ${ }^{4}$ Roselyne Vallo, ${ }^{3}$ Chipepo Kankasa, ${ }^{5,6}$ James K Tumwine, ${ }^{7}$ Mandisa Singata-Madliki, ${ }^{8}$ Kim Harper, ${ }^{8}$ G Justus Hofmeyr, ${ }^{8}$ Philippe Van de Perre, ${ }^{3}$ Thorkild Tylleskär, ${ }^{1}$ on behalf of the ANRS 12174 Trial Group

To cite: Somé EN, Engebretsen IMS, Nagot N, et al. HIV-1 disease progression in immune-competent HIV1 -infected and breastfeeding mothers participating in the ANRS 12174 clinical trial in Burkina Faso, South Africa, Uganda and Zambia: a cohort study. BMJ Open 2018;8:e019239. doi:10.1136/ bmjopen-2017-019239

- Prepublication history for this paper is available online. To view these files, please visit the journal online (http://dx.doi. org/10.1136/bmjopen-2017019239).

Received 24 August 2017 Revised 17 December 2017 Accepted 14 February 2018

Check for updates

For numbered affiliations see end of article.

Correspondence to Dr Eric Nagaonle Somé; eric.nsome@gmail.com

\section{ABSTRACT}

Objective We have assessed HIV-1 disease progression among HIV-1-positive mothers in relation to duration of any or exclusive breast feeding in the context of ANRS 12174 trial.

Methods The analysis was completed on 203, 212, 272 and 529 HIV-1-positive and lactating mothers with CD4 count $>350$ cells/ $\mu \mathrm{L}$ from Burkina Faso, South Africa, Uganda and Zambia, respectively. The trial compared lamivudine and lopinavir/ritonavir as a peri-exposure prophylaxis during a 50-week follow-up time. A multiple logistic regression model was run with the mothers' weight, CD4 count and HIV-1 viral load as separate dependent variables, then combined into a dependent composite endpoint called HIV-1 disease progression where HIV-1 viral load was replaced by the HIV-1 clinical stage. Exclusive or predominant breast feeding (EPBF) and any breastfeeding duration were the key explanatory variables.

Results In the adjusted model, the associations between EPBF duration and weight change, CD4 cell count and the HIV-1 viral load were consistently insignificant. The CD4 cell count was associated with a significantly higher mothers' body mass index (BMI; a mean increase of 4.9 (95\% Cl 2.1 to 7.7$)$ CD4 cells/ $\mu \mathrm{L}$ per each additional kilogram per square metre of $\mathrm{BMI})$ and haemoglobin concentration $(19.4$ (95\% Cl 11.4 to 27.4 ) CD4 cells/ $\mu \mathrm{L}$ per each additional gram per decilitre of haemoglobin concentration). There was no significant association between EPBF duration and HIV-1 disease progression. A higher education level was a factor associated with a slower HIV-1 disease progression.

Conclusion Breast feeding was not a risk factor for a faster progression of HIV-1 disease in mothers of this cohort with a baseline CD4 cell count $>350$ cells $/ \mu \mathrm{L}$. Trial registration number NCT0064026; Post-results.

\section{Strengths and limitations of this study}

- Our study has been implemented in four countries in Africa, namely Burkina Faso (West), South Africa and Zambia (South), and Uganda (East), which made our sample representative of the wider sub-Sahara African population.

- The data were collected in the context of a rigorous clinical trial, which minimised the loss to follow-up, the missing data as well as other data collection errors, and therefore improved the quality of our data.

- However, the selection associated with the environment of a clinical trial, usually quite different from a routine environment, may have biased our findings.

- Nonetheless, the variables analysed separately as dependent variables or as part of our composite endpoints (mother's weight, CD4 cell count, HIV-1 viral load or HIV-1 clinical stage) were sufficiently robust and had a high validity.

\section{INTRODUCTION}

In 2015, 36.7 (34.0-39.8) million people were infected with HIV. Among them, 17.4 (16.120.0) million were women of childbearing age. ${ }^{1}{ }^{2}$ HIV-1 prevalence was estimated between $5.3 \%$ and $6.5 \%$ among pregnant women in sub-Saharan Africa. ${ }^{3}$ Because of the almost irreversible immune activation involved, HIV-1 infection creates a condition of metabolic stress that may result in wasting and immune depression. ${ }^{4-7}$ Ten per cent weight loss and a CD 4 count of $<350$ cells $/ \mu \mathrm{L}$ in the context of HIV-1 infection have been recognised as major criteria of the diagnosis of AIDS. ${ }^{8}$ This weight loss is also associated 
with a higher risk of mortality in HIV-1-infected breastfeeding mothers. ${ }^{9}$ Furthermore, HIV-1 is a major cause of maternal mortality in affected countries in Southern Africa. About $25 \%$ of pregnancy-related deaths in sub-Saharan Africa are attributable to $\mathrm{HIV},{ }^{10}$ and $88 \%$ of deaths among pregnant and postpartum women with HIV infection are attributable to the virus. ${ }^{11}$

In women, pregnancy is, though a physiological condition, a period of increased metabolic activities and synthesis requiring a supplement of energy and nutrients. After delivery, breast feeding prolongs the increased metabolic demands. Despite this, WHO still recommends HIV-1-infected women to breast feed as the best choice for the infant and the mother ${ }^{12}$ in contexts where replacement feeding does not meet AFASS (affordable, feasible, available, safe and sustainable) criteria.

There have been conflicting results on assessment of the impact of breast feeding in HIV-1-infected mothers. Some studies found that breast feeding was harmful to HIV-positive mothers by either accelerating HIV disease progression as assessed by the mother's weight loss, a decrease in CD4 cell count or even an increased risk of maternal mortality, suggesting that metabolic, immunological or hormonal changes associated with breast feeding may accelerate HIV-1 disease progression in postpartum mothers. ${ }^{13-15}$ Others found no effect on the mothers' health assessed by death, development of a low CD4 cell count, anaemia or excessive weight loss. ${ }^{1617}$ Some studies have found breast feeding protective, allowing weight gain in HIV-1-infected breastfeeding mothers. ${ }^{1518-22}$

In the ANRS 12174 trial, we assessed mothers' HIV-1 disease progression (measured by the change in weight, CD4 cell count and HIV-1 disease stage as per WHO classification) in relation to exclusive breast feeding or duration of any breast feeding during the infant first 6 months of life and until week 50 post partum.

\section{METHODS}

\section{Study design}

The ANRS 12174 clinical trial in Ouagadougou (Burkina Faso), East London (South Africa), Mbale (Uganda) and Lusaka (Zambia) was conducted from 2009 to 2013. The protocol and the main outcome have been published. ${ }^{23} 24$ Briefly, a cohort of HIV-1-infected, pregnant women, at the time not eligible for highly active antiretroviral therapy because CD4 count was $>350$ cells $/ \mu \mathrm{L}$, aged 18 or above and planning to breast feed were identified from antenatal clinics between 28 and 40 weeks of amenorrhoea. As part of the HIV post-test counselling session, they were informed on the different feeding options for their babies. Only women intending to breast feed were referred to the research clinic for further assessment of the inclusion criteria during the antenatal period and again with their child within 6 days after birth, for an enrolment and randomisation at day 7 post partum. From 28 weeks of pregnancy to day 7 after birth, programmatic mother-to-child transmission prophylaxis was implemented with antepartum zidovudine, intrapartum singledose nevirapine and zidovudine-lamivudine for mothers and nevirapine for infants for 7 days postpartum. Twins and triplets, infants with positive HIV-1 DNA PCR test result at day 7 ( \pm 2 days) post partum, low birthweight or ill babies (ranked grade II or above of the ANRS classification for adverse events) were excluded. ${ }^{25}$ The intervention provided an infant prophylaxis in the breastfeeding period plus 1 week from day 7 to 50 weeks of age with either lopinavir/ritonavir or lamivudine.

\section{Data management and analysis}

Data were collected on a paper case-report form or directly entered online using the Electronic Data capture system: OpenClinica (http://www.openclinica.com). Twenty-four-hour and 1-week breastfeeding recalls were collected during the enrolment visit at day $7 \pm 2$ days after birth and the 13 monthly scheduled follow-up visits that started at week 2. During these visits, mothers were asked in particular if they gave their infants other foods/liquids as well as breast milk. Prelacteal feeding data-

defined as any food item except mothers' milk given to infants before initial breast feeding-were also collected at the enrolment visit.

The mothers at each visit were categorised into the following groups: (1) exclusive breast feeding, EBF (only breast milk being given to the infant without any other food or liquid, except medically prescribed drugs or vitamins); (2) predominant breastfeeding, PBF (breast milk with some liquid-based food, such as juice, tea, sugar water and salt water, including glucose without any kind of formula, or animal milk); and (3) mixed feeding, MF (breast milk with other solid-based or liquid-based food, including other kinds of milk). We thereafter combined EBF and PBF into one group called 'exclusive or predominant breastfeeding' (EPBF) as PBF presented few cases and was assessed as having much the same risk as EBF, at least with regard to postnatal HIV transmission. ${ }^{26}$

During the follow-up visits, the mothers underwent a clinical assessment, including weight measurement and HIV-1 infection staging at the first screening visit or screening one (between 28 and 40 weeks of gestation), day 7 post partum, weeks 26 and 50; CD4 cell count analysis at screening one, weeks 26 and 50; and HIV-1 viral load at screening one, day 7, weeks $6,14,26,38$ and 50. The dependent variables were mothers' weight, CD4 cell count and HIV-1 viral load considered separately and measured at the same time points as per above. We generated a new variable called 'weight loss', which was calculated as the mothers' weight at W26 (because of missing data, mothers' weights were not available for week 50) minus the baseline weight at day 7 post partum, which was compared with the baseline weight to assess if the loss had reached $10 \%$. Furthermore, we combined CD4 cell count, mothers' weight loss and HIV-1 disease stage as per WHO classification to create the composite endpoint called 'HIV-1 disease progression'. HIV-1 disease progression was 
accelerated when CD4 cell count decreased to $<350$ cells/ $\mu \mathrm{L}$, or the HIV-1 infection was assessed by the trial physician at stage 3 or above, or the mothers lost $>10 \%$ of their weight; otherwise, HIV-1 disease progression was deemed absent or slow. Our main independent variable was EPBF (until week 26 post partum) or any breastfeeding (until week 50 post partum) duration. The data were collected by trained physicians, pharmacists, biologists and counsellors. Seca-brand scales and stadiometers were used to measure the mother's height and weight. Weights were rounded to the nearest $10 \mathrm{~g}$ and the height to the nearest millimetre. Weight and height were measured twice based on the WHO guidelines (http://www.who.int/ childgrowth/training/en/).

We first ran linear mixed-effect models that considered separately the mothers' weight, CD4 cell count and HIV-1 viral load changes as dependent variables, and EPBF or any breast feeding as key independent variables. The loss to follow-up were censored in a survival analysis completed to build the EPBF and any breastfeeding variables. ${ }^{27}$ When the inter-country variability was not significant, a linear multivariate regression analysis was run. We ran a logistic regression regarding the composite endpoint. Adjustment covariates included baseline variables measured at the screening one visit (body mass index (BMI), education level, marital status, haemoglobin concentration) or on day 7 post partum (mode of delivery, breastfeeding initiation time, the baby's gender and the trial arm). These multivariate analyses were run taking all participants together and also as two strata comprising South
African mothers (stratum 1) and Burkina Faso, Uganda and Zambia together (stratum 2) because South Africa presented important socioeconomic, cultural and demographic differences compared with the other countries. For continuous variables, the mean values with $95 \%$ CI were estimated, and for categorical variables, percentages were used. Associations between variables were tested using the $\chi^{2}$ test for categorical variables. STATA/SE V.13.1 statistical software has been used for the analyses.

\section{Ethics}

Prior to enrolment, the mothers signed a written informed consent and assent forms for themselves and their children, respectively. The trial was conducted according to the sponsor (ANRS) ethic charter, Good Clinical Practices and the principles of the Helsinki declaration.

\section{RESULTS}

In the ANRS 12174 trial, 1273 mother-infant pairs were randomised and six were excluded due to protocol violations. Of the remaining 1267 participants, 204 were from Ouagadougou, 222 from East London, 278 from Mbale and 563 from Lusaka. In all, 42 were excluded from analysis due to lack of breastfeeding data after inclusion, 7 due to inaccurate feeding duration data and 2 women had no data on weights. The analysis included 1216 subjects. The complete flow chart has been published elsewhere. ${ }^{27}$ The mean baseline weight, the percentage of educated and employed women was highest, and the mean EPBF

Table 1a Baseline characteristics collected at screening one or on day 7 post partum and breastfeeding duration data (continuous variables)

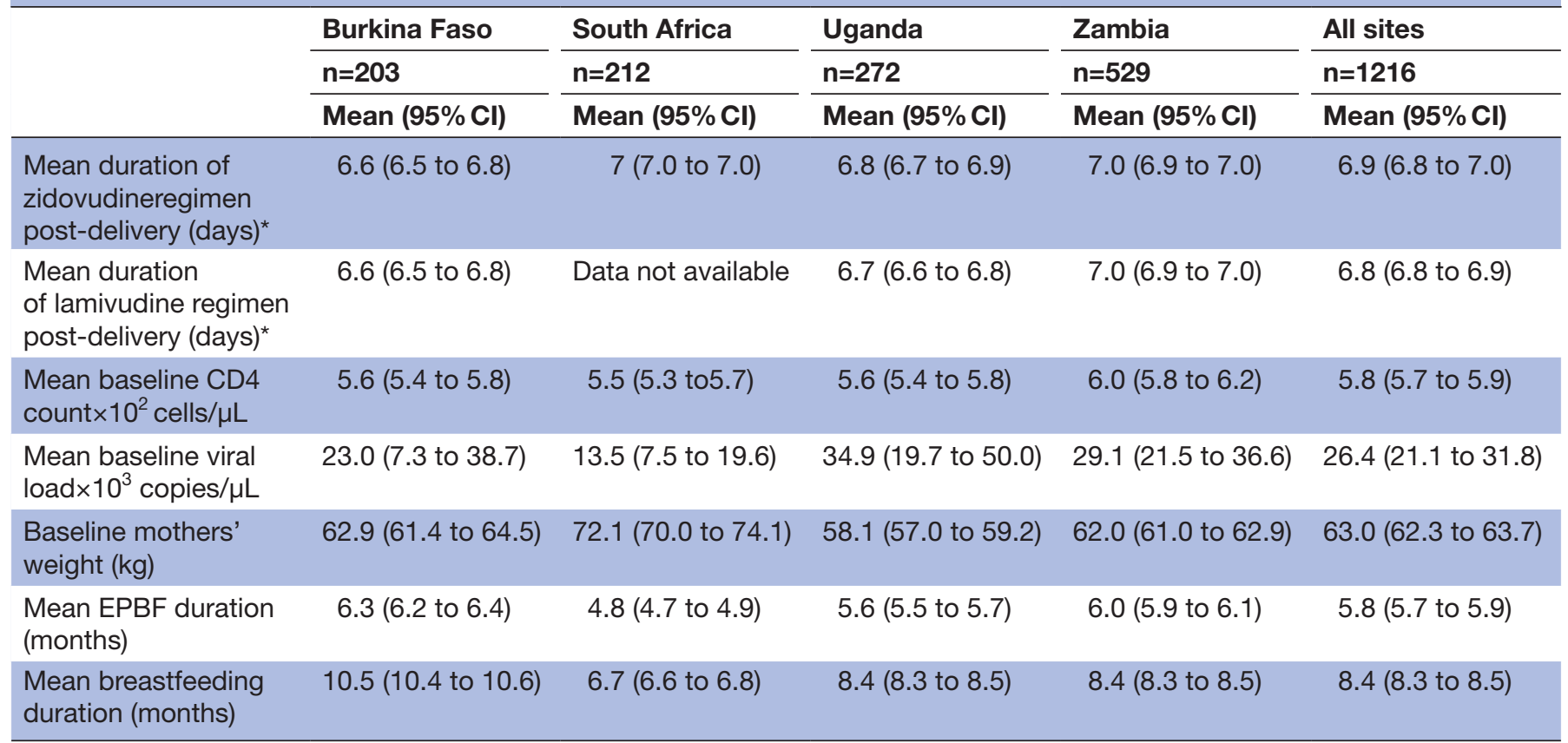

${ }^{*}$ AZT and 3TC (zidovudine and lamivudine) are usually administered together. However, in our data collection tool (the questionnaire), the investigators had to ask specifically and separately the question for AZT and 3TC. We suspect that they may have been some reporting errors, creating slight differences in the percentages of women who complied with the prophylaxis requirements.

EPBF, exclusive or predominant breast feeding. 
Table 1b Baseline characteristics collected at screening one or on day 7 post partum and breastfeeding duration data (categorical variables)

\begin{tabular}{|c|c|c|c|c|c|}
\hline & Burkina Faso & South Africa & Uganda & Zambia & All sites \\
\hline & $n=203$ & $n=212$ & $\mathrm{n}=272$ & $n=529$ & $n=1216$ \\
\hline & $\%(95 \% \mathrm{Cl})$ & $\%(95 \% \mathrm{Cl})$ & $\%(95 \% \mathrm{Cl})$ & $\%(95 \% \mathrm{Cl})$ & $\%(95 \% \mathrm{Cl})$ \\
\hline \multicolumn{6}{|c|}{ Mother's age group (years) } \\
\hline Below 25 & 26.2 (20.5 to 32.6$)$ & 34.4 (28.3 to 41.1$)$ & 39.3 (33.7 to 45.3 ) & 37.8 (33.8 to 42.0$)$ & 35.6 (33.0 to 38.3 ) \\
\hline $25-30$ & 36.9 (30.6 to 43.8 ) & 31.2 (25.2 to 37.7$)$ & 35.7 (30.2 to 41.5 ) & 33.1 (29.2 to 37.2$)$ & 34.0 (31.3 to 36.7$)$ \\
\hline 30 and above & 36.9 (30.6 to 43.8 ) & 34.4 (28.3 to 41.1$)$ & 25.0 (20.2 to 30.5$)$ & 29.1 (25.4 to 33.1 ) & 30.4 (27.9 to 33.1$)$ \\
\hline HIV stage 1 & 93.1 (88.7 to 95.9 ) & 98.6 (95.7 to 99.5$)$ & 92.3 (88.4 to 94.9 ) & 99.8 (98.7 to 100.0$)$ & 96.8 (95.6 to 97.6$)$ \\
\hline \multicolumn{6}{|l|}{ Education } \\
\hline $\begin{array}{l}\text { Did not } \\
\text { complete } \\
\text { primary school }\end{array}$ & 68.5 (61.7 to 74.5$)$ & 8.5 (5.4 to 13.1$)$ & 48.5 (42.6 to 54.5$)$ & 28.2 (24.5 to 32.2 ) & 36.0 (33.4 to 0.38 .8$)$ \\
\hline $\begin{array}{l}\text { Completed } \\
\text { primary school }\end{array}$ & 7.4 (4.5 to 11.9$)$ & 0.5 (0.1 to 3.3$)$ & 15.8 (11.9 to 20.6$)$ & 18.5 (15.4 to 22.1$)$ & 12.9 (11.1 to 14.9$)$ \\
\hline $\begin{array}{l}\text { Secondary } \\
\text { school and } \\
\text { more }\end{array}$ & 24.1 (18.7 to 30.5 ) & 91.0 (86.4 to 94.2$)$ & $35.7(0.30 .2$ to 41.5$)$ & 53.3 (49.0 to 57.5$)$ & 51.1 (48.2 to 53.9$)$ \\
\hline $\begin{array}{l}\text { Marital status } \\
\text { (married) }\end{array}$ & 90.6 (85.8 to 94.0 ) & 39.1 (32.8 to 45.9 ) & 82.0 (76.9 to 86.1$)$ & 88.7 (85.7 to 91.1$)$ & 78.9 (76.5 to 81.1$)$ \\
\hline $\begin{array}{l}\text { Occupation } \\
\text { (employed) }\end{array}$ & 8.9 (5.6 to 13.6$)$ & 41.5 (35.0 to 48.3 ) & 35.3 (29.8 to 41.2 ) & 17.0 (14.0 to 20.5$)$ & 24.0 (21.7 to 26.5$)$ \\
\hline Primipara & 21.7 (16.5 to 27.9$)$ & 33.5 (27.4 to 40.1$)$ & 18.0 (13.9 to 23.0$)$ & 20.6 (17.4 to 24.3 ) & 22.4 (20.2 to 24.9$)$ \\
\hline Vaginal delivery & 93.6 (89.3 to 96.2 ) & 65.1 (58.4 to 71.2 ) & 93.4 (89.7 to 95.8 ) & 96.2 (94.2 to 97.5$)$ & 89.7 (87.9 to 91.3$)$ \\
\hline $\begin{array}{l}\text { Breastfeeding } \\
\text { initiation time } \\
\text { (within } 1 \text { hour) }\end{array}$ & 6.9 (4.1 to 11.3$)$ & 51.4 (44.7 to 58.1$)$ & 55.9 (49.9 to 61.7$)$ & 80.7 (77.1 to 83.9$)$ & 57.7 (54.9 to 60.5$)$ \\
\hline Lamivudine arm & 49.7 (42.9 to 56.6 ) & 51.9 (45.1 to 58.6$)$ & 49.6 (43.7 to 55.6 ) & 50.3 (46.0 to 54.5 ) & 50.3 (47.5 to 53.1$)$ \\
\hline Female baby & 41.9 (35.2 to 48.8$)$ & 49.1 (42.4 to 55.8 ) & 52.9 (46.0 to 58.8$)$ & 48.4 (44.1 to 52.7$)$ & 48.4 (45.6 to 51.2$)$ \\
\hline
\end{tabular}

and any breastfeeding durations shortest in South Africa where the HIV-1 viral load was also the lowest (table 1a and $\mathrm{b}$ ).

Overall, in the adjusted model, the association between EPBF duration and weight change was negative and non-significant. Mothers who completed secondary school had a significant mean increase of $1.1 \mathrm{~kg}$ compared with those who did not complete primary school (table $2 \mathrm{a}$ ).

The association between CD4 cell count and EPBF duration was non-significant (5.4 (95\% CI -0.1 to 10.9) and 4.5 (95\% CI -6.2 to 15.1$) \mathrm{CD} 4$ cells/ $\mu \mathrm{L}$ increase per month of EPBF duration at univariate and multivariate analyses, respectively). The association was significantly positive between the mothers' baseline BMI, haemoglobin concentration and $\mathrm{CD} 4$ cell count yielding a mean increase of $4.9(95 \% \mathrm{CI} 2.1$ to 7.7$) \mathrm{CD} 4$ cells $/ \mu \mathrm{L}$ per additional BMI unit and 19.4 (95\% CI 11.4 to 27.4$)$ CD4 cells/ $\mu \mathrm{L}$ per additional unit of haemoglobin throughout the EPBF period (table 2b).

There was no significant association between HIV-1 viral load and EPBF duration. The heavier and older mothers, those who delivered female babies and the best educated women group had a significantly lower mean viral load in the multivariate analysis. The mothers allocated to the lopinavir/ritonavir group had a significantly higher mean viral load than the ones in the lamivudine arm (table 2c).

We found no significant association between EPBF duration and HIV-1 disease progression. However, randomisation to the lopinavir/ritonavir arm or being a single mother led to a significantly adjusted OR of 1.3 (95\% CI 1.0 to $1.6 ; \mathrm{P}=0.04)$ and 1.6 (95\% CI 1.3 to 2.1 ), respectively (table $2 \mathrm{~d}$ ).

Considering any breastfeeding duration, there was no weight change at univariate and multivariate analyses overall (table 3a). Still regarding any breast feeding, overall, there was a significant mean increase of 5.7 (95\% CI 0.4 to 10.9) CD4 cells $/ \mu \mathrm{L}$ per month of any breast feeding. We found also that being a single mother was associated with a mean decrease of -43.3 (95\% CI -72.8 to -13.7$)$ CD4 cells/ $\mu \mathrm{L}$ as compared with married ones (table $3 \mathrm{~b}$ ). Any breastfeeding duration was also associated with a significantly higher mean viral load (table 3c). Analysis with any breastfeeding pattern and HIV-1 disease progression showed the same associations as EPBF and HIV-1 disease progression (table 3d). 
Table 2a Mothers' weight change according to EPBF duration adjusted to different covariates: stratification presenting South Africa versus the other sites and pooled analysis

\begin{tabular}{|c|c|c|c|c|c|c|}
\hline & \multicolumn{2}{|l|}{ South Africa } & \multicolumn{2}{|c|}{$\begin{array}{l}\text { Burkina Faso, Uganda and } \\
\text { Zambia }\end{array}$} & \multicolumn{2}{|c|}{ Pooled analysis } \\
\hline & $\begin{array}{l}\text { Unadjusted } \\
\text { coefficient } \\
(95 \% \mathrm{Cl})\end{array}$ & $\begin{array}{l}\text { Adjusted } \\
\text { coefficient } \\
(95 \% \mathrm{Cl})\end{array}$ & $\begin{array}{l}\text { Unadjusted } \\
\text { coefficient } \\
(95 \% \mathrm{Cl})\end{array}$ & $\begin{array}{l}\text { Adjusted } \\
\text { coefficient } \\
(95 \% \mathrm{Cl})\end{array}$ & $\begin{array}{l}\text { Unadjusted } \\
\text { coefficient } \\
(95 \% \mathrm{Cl})\end{array}$ & $\begin{array}{l}\text { Adjusted } \\
\text { coefficient } \\
(95 \% \mathrm{Cl})\end{array}$ \\
\hline \multicolumn{7}{|c|}{ Dependent variable=mother's weight } \\
\hline $\begin{array}{l}\text { EPBF duration } \\
\text { (months) }\end{array}$ & $\begin{array}{l}0.1 \\
(-0.7 \text { to } 0.9)\end{array}$ & $\begin{array}{l}-0.2 \\
(-0.6 \text { to } 0.1)\end{array}$ & $\begin{array}{l}-0.1 \\
(-0.5 \text { to } 0.3)\end{array}$ & $\begin{array}{l}0.1 \\
(-0.0 \text { to } 0.3)\end{array}$ & $\begin{array}{l}-0.2 \\
(-0.5 \text { to } 0.2)\end{array}$ & $\begin{array}{l}-0.1 \\
(-0.2 \text { to } 0.1)\end{array}$ \\
\hline $\begin{array}{l}\text { Baseline BMI } \\
\left(\mathrm{kg} / \mathrm{m}^{2}\right)\end{array}$ & $\begin{array}{l}2.5 \\
(2.4 \text { to } 2.7)\end{array}$ & $\begin{array}{l}2.4 \\
(2.3 \text { to } 2.6)\end{array}$ & $\begin{array}{l}2.5 \\
(2.4 \text { to } 2.6)\end{array}$ & $\begin{array}{l}2.4 \\
\text { (2.3 to } 2.5)\end{array}$ & $\begin{array}{l}2.5 \\
(2.4 \text { to } 2.6)\end{array}$ & $\begin{array}{l}2.4 \\
\text { (2.3 to } 2.5)\end{array}$ \\
\hline Mother's age (years) & $\begin{array}{l}0.8 \\
(0.5 \text { to } 1.2)\end{array}$ & $\begin{array}{l}0.1 \\
(0.0 \text { to } 0.3)\end{array}$ & $\begin{array}{l}0.5 \\
(0.4 \text { to } 0.6)\end{array}$ & $\begin{array}{l}0.1 \\
\text { (0.1 to } 0.2)\end{array}$ & $\begin{array}{l}0.5 \\
(0.4 \text { to } 0.7)\end{array}$ & $\begin{array}{l}0.1 \\
\text { (0.1 to } 0.2)\end{array}$ \\
\hline \multicolumn{7}{|l|}{ HIV disease stage } \\
\hline \multicolumn{7}{|l|}{ HIV stage 1} \\
\hline HIV stage $>1$ & $\begin{array}{l}12.4 \\
(-4.5 \text { to } 29.4)\end{array}$ & $\begin{array}{l}6.7 \\
(0.4 \text { to } 13.1)\end{array}$ & $\begin{array}{l}-2.8 \\
(-6.4 \text { to } 0.8)\end{array}$ & & & \\
\hline \multicolumn{7}{|l|}{ Education } \\
\hline $\begin{array}{l}\text { Did not complete } \\
\text { primary school }\end{array}$ & & & 1 & 1 & 1 & 1 \\
\hline $\begin{array}{l}\text { Completed } \\
\text { primary school }\end{array}$ & & & $\begin{array}{l}3.9 \\
(2.0 \text { to } 5.9)\end{array}$ & $\begin{array}{l}0.2 \\
(-0.7 \text { to } 1.1)\end{array}$ & $\begin{array}{l}4.4 \\
(2.2 \text { to } 6.5)\end{array}$ & $\begin{array}{l}0.6 \\
(-0.3 \text { to } 1.5)\end{array}$ \\
\hline $\begin{array}{l}\text { Secondary school } \\
\text { and more }\end{array}$ & & & $\begin{array}{l}2.7 \\
(1.2 \text { to } 4.1)\end{array}$ & $\begin{array}{l}0.7 \\
(0.1 \text { to } 1.4)\end{array}$ & $\begin{array}{l}3.1 \\
(1.5 \text { to } 4.6)\end{array}$ & $\begin{array}{l}1.1 \\
(0.4 \text { to } 1.8)\end{array}$ \\
\hline \multicolumn{7}{|l|}{ Marital status } \\
\hline $\begin{array}{l}\text { Married/ } \\
\text { cohabiting mothers }\end{array}$ & 1 & & & & 1 & \\
\hline Single mothers & $\begin{array}{l}-3.1 \\
(-7.2 \text { to } 0.9)\end{array}$ & & & & $\begin{array}{l}-1.2 \\
(-3.0 \text { to } 0.5)\end{array}$ & \\
\hline \multicolumn{7}{|l|}{ Delivery } \\
\hline Vaginal delivery & 1 & & 1 & & 1 & 1 \\
\hline C-section delivery & $\begin{array}{l}3.7 \\
(-0.4 \text { to } 7.9)\end{array}$ & & $\begin{array}{l}4.5 \\
(1.5 \text { to } 7.6)\end{array}$ & & $\begin{array}{l}4.4 \\
\text { (2.1 to } 6.7)\end{array}$ & $\begin{array}{l}-1.1 \\
(-2.1 \text { to }-0.1)\end{array}$ \\
\hline \multicolumn{7}{|l|}{ Parity } \\
\hline Primipara & 1 & & 1 & & 1 & - \\
\hline Multipara & $\begin{array}{l}6.1 \\
(1.9 \text { to } 10.3)\end{array}$ & & $\begin{array}{l}3.1 \\
\text { (1.4 to } 4.7)\end{array}$ & & $\begin{array}{l}3.9 \\
(2.3 \text { to } 5.4)\end{array}$ & - \\
\hline \multicolumn{7}{|l|}{ Trial arm } \\
\hline Lamivudine arm & 1 & 1 & 1 & 1 & 1 & 1 \\
\hline $\begin{array}{l}\text { Lopinavir/ } \\
\text { ritonavir arm }\end{array}$ & $\begin{array}{l}2.0 \\
(-2.0 \text { to } 6.1)\end{array}$ & $\begin{array}{l}0.8 \\
(-0.7 \text { to } 2.3)\end{array}$ & $\begin{array}{l}-0.1 \\
(-1.4 \text { to } 1.3)\end{array}$ & $\begin{array}{l}-0.3 \\
(-0.9 \text { to } 0.2)\end{array}$ & $\begin{array}{l}0.3 \\
(-1.0 \text { to } 1.6)\end{array}$ & $\begin{array}{l}-0.1 \\
(-0.7 \text { to } 0.4)\end{array}$ \\
\hline
\end{tabular}

$\mathrm{BMI}$, body mass index; EPBF, exclusive or predominant breast feeding.

In the stratified analysis, we found that EPBF duration had no influence on mothers' weight, CD4 count or HIV-1 viral load, whatever the stratum. HIV-1 disease progression was not associated either with EPBF duration (table 2a, b, c and d). In stratum 2, C-section delivery was associated with an increase in $\mathrm{CD} 4$ cell count (table 2b), whereas delivering a female baby and being educated beyond secondary school were associated with a decrease in HIV-1 viral load (table 2c).

In South Africa, initiating breast feeding 1 hour post-delivery and being a single mother were related to an increase in HIV-1 viral load. In both strata, C-section delivery and multiparity were also related to an increase in HIV-1 viral load. There was no association between any breast feeding and the mothers' weight, CD4 cell count and HIV-1 disease progression in any of the strata (table $3 \mathrm{a}, \mathrm{b}$ and d). However, any breastfeeding duration was associated with an increase of the HIV-1 viral load in South African women (table 3c).

\section{DISCUSSION}

Considered separately, there appeared to be no variations in the mothers' weight, CD4 cell count and HIV-1 viral 
Table 2b Mothers' CD4 cell count change according to EPBF duration adjusted to different covariates: stratification presenting South Africa versus the other sites and pooled analysis

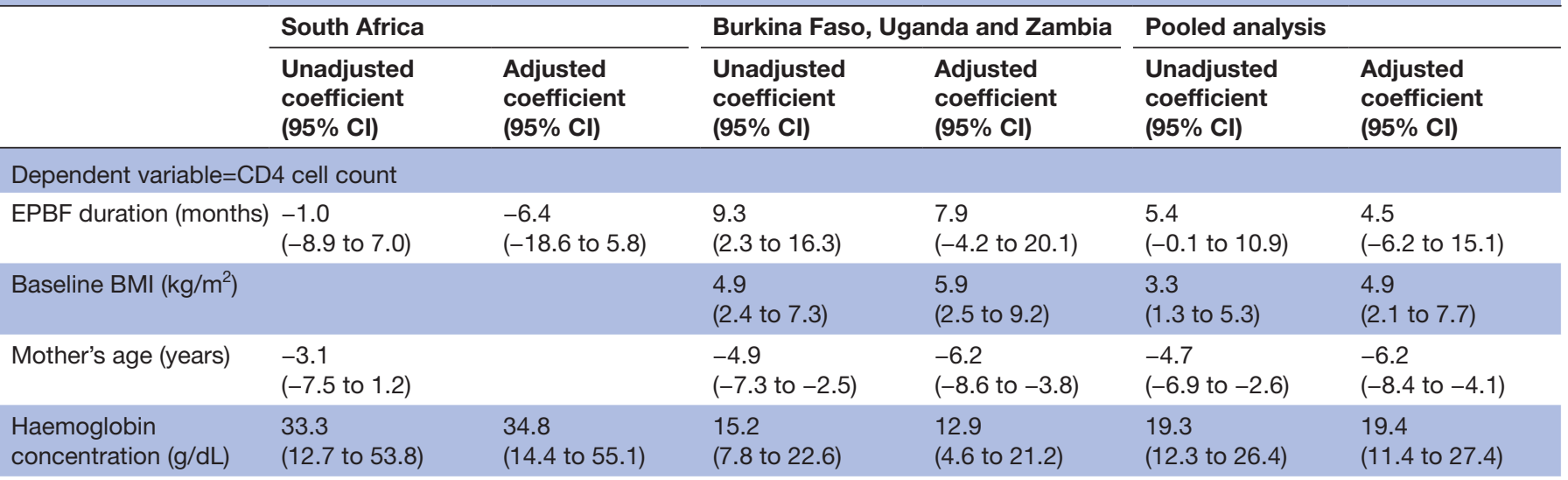

Dependent variable $=\mathrm{CD} 4$ cell count

Breastfeeding initiation

time

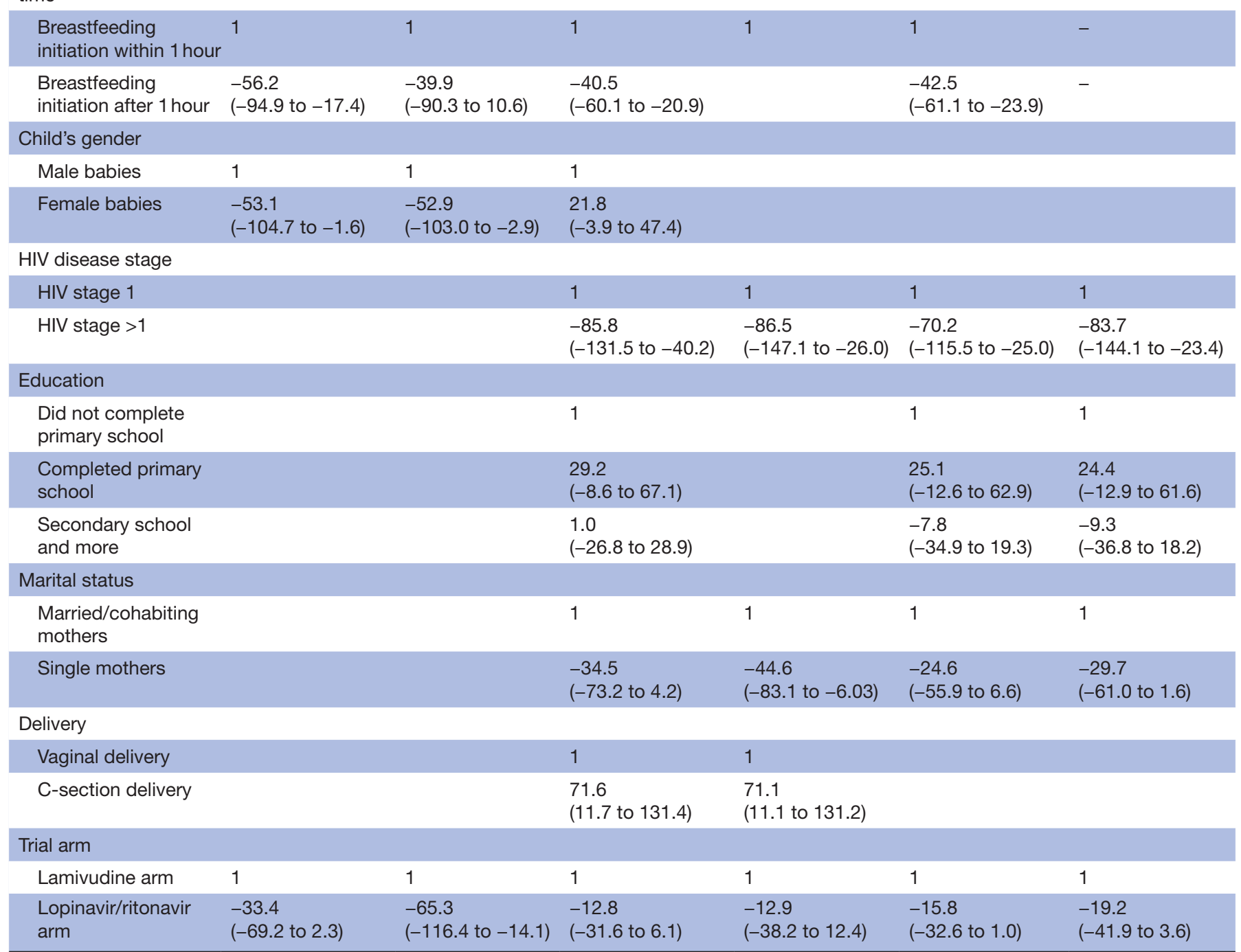

$\mathrm{BMI}$, body mass index; EPBF, exclusive or predominant breast feeding.

load related to EPBF or any breast feeding. The same conclusion applied to these outcomes was combined in a composite endpoint representing HIV-1 disease progression. Unsurprisingly, mothers' baseline BMIs were consistently associated with an increase in the mothers' weight and CD4 cell count, and with a lower mean HIV-1 viral load for both EPBF and any breastfeeding groups.

In a review of the literature on weight change in the postpartum period, there appeared to be no association between breast feeding or generally between the mode 
Table 2c Mothers' HIV-1 viral load change according to EPBF duration adjusted to different covariates: stratification presenting South Africa versus the other sites and pooled analysis

\begin{tabular}{|c|c|c|c|c|}
\hline South Africa & & Burkina Fasc & nda and Zambia & Pooled analy \\
\hline $\begin{array}{l}\text { Unadjusted } \\
\text { coefficient } \\
(95 \% \text { CI) }\end{array}$ & $\begin{array}{l}\text { Adjusted } \\
\text { coefficient } \\
(95 \% \mathrm{CI})\end{array}$ & $\begin{array}{l}\text { Unadjusted } \\
\text { coefficient } \\
(95 \% \text { CII }\end{array}$ & $\begin{array}{l}\text { Adjusted } \\
\text { coefficient } \\
(95 \% \mathrm{CIN})\end{array}$ & $\begin{array}{l}\text { Unadjusted } \\
\text { coefficient } \\
(95 \% \text { CII }\end{array}$ \\
\hline
\end{tabular}

\begin{tabular}{|c|c|c|c|c|c|c|}
\hline & & & & & & \\
\hline \multicolumn{7}{|c|}{ Dependent variable $=$ viral load $\left(\right.$ coefficient $\left.\times 10^{3}\right)$} \\
\hline EPBF duration (months) & $\begin{array}{l}4.5 \\
(-3.4 \text { to } 12.4)\end{array}$ & $\begin{array}{l}-3.6 \\
(-11.5 \text { to } 4.4)\end{array}$ & $\begin{array}{l}5.4 \\
(-7.118 .0)\end{array}$ & $\begin{array}{l}2.0 \\
(-11.315 .4)\end{array}$ & $\begin{array}{l}6.2 \\
(-2.5 \text { to } 14.9)\end{array}$ & $\begin{array}{l}1.7 \\
(-7.3 \text { to } 10.8)\end{array}$ \\
\hline Baseline BMI $\left(\mathrm{kg} / \mathrm{m}^{2}\right)$ & $\begin{array}{l}-7.7 \\
(-10.9 \text { to }-4.6)\end{array}$ & $\begin{array}{l}-14.5 \\
(-17.9 \text { to }-11.0)\end{array}$ & $\begin{array}{l}-4.7 \\
(-8.5 \text { to }-1.0)\end{array}$ & $\begin{array}{l}-5.7 \\
(-9.8 \text { to }-1.6)\end{array}$ & $\begin{array}{l}-6.5 \\
(-9.2 \text { to }-3.8)\end{array}$ & $\begin{array}{l}-8.0 \\
(-11.0 \text { to }-4.9)\end{array}$ \\
\hline Mother's age (years) & $\begin{array}{l}-2.7 \\
(-5.3 \text { to }-0.1)\end{array}$ & $\begin{array}{l}-2.7 \\
(-5.5 \text { to } 0.1)\end{array}$ & $\begin{array}{l}-1.9 \\
(-4.6 \text { to } 0.8)\end{array}$ & $\begin{array}{l}-4.5 \\
(-7.7 \text { to }-1.4)\end{array}$ & $\begin{array}{l}-2.1 \\
(-4.3 \text { to } 0.1)\end{array}$ & $\begin{array}{l}-4.5 \\
(-7.0 \text { to }-2.0)\end{array}$ \\
\hline \multicolumn{7}{|l|}{$\begin{array}{l}\text { Breastfeeding initiation } \\
\text { time }\end{array}$} \\
\hline \multicolumn{2}{|l|}{$\begin{array}{l}\text { Breastfeeding } \\
\text { initiation }<1 \text { hour }\end{array}$} & 1 & & & & \\
\hline $\begin{array}{l}\text { Breastfeeding } \\
\text { initiation }>1 \text { hour }\end{array}$ & $\begin{array}{l}70.5 \\
(41.3 \text { to } 99.7)\end{array}$ & $\begin{array}{l}45.1 \\
(13.5 \text { to } 76.7)\end{array}$ & & & & \\
\hline \multicolumn{7}{|l|}{ Child's gender } \\
\hline Male babies & 1 & 1 & 1 & 1 & 1 & 1 \\
\hline Female babies & $\begin{array}{l}-49.1 \\
(-79.4 \text { to } 18.7)\end{array}$ & & $\begin{array}{l}-19.5 \\
(-48.5 \text { to } 9.4)\end{array}$ & $\begin{array}{l}-36.5 \\
(-66.0 \text { to } 7.2)\end{array}$ & $\begin{array}{l}-25.3 \\
(-49.2 \text { to }-1.4)\end{array}$ & $\begin{array}{l}-35.2 \\
(-59.2 \text { to }-11.1)\end{array}$ \\
\hline \multicolumn{7}{|l|}{ Education } \\
\hline \multicolumn{2}{|l|}{$\begin{array}{l}\text { Did not complete } \\
\text { primary school }\end{array}$} & & 1 & 1 & 1 & 1 \\
\hline \multicolumn{2}{|l|}{$\begin{array}{l}\text { Completed primary } \\
\text { school }\end{array}$} & & $\begin{array}{l}-10.2 \\
(-53.9 \text { to } 33.5)\end{array}$ & $\begin{array}{l}2.9 \\
(-41.4 \text { to } 47.2)\end{array}$ & $\begin{array}{l}-5.0 \\
(-45.1 \text { to } 35.2)\end{array}$ & $\begin{array}{l}13.4 \\
(-26.9 \text { to } 53.8)\end{array}$ \\
\hline \multicolumn{2}{|l|}{$\begin{array}{l}\text { Secondary school } \\
\text { and more }\end{array}$} & & $\begin{array}{l}-76.7 \\
(-108.1 \text { to }-45.3)\end{array}$ & $\begin{array}{l}-73.4 \\
(-105.9 \text { to }-41.0)\end{array}$ & $\begin{array}{l}-72.7 \\
(-98.7 \text { to }-46.7)\end{array}$ & $\begin{array}{l}-62.0 \\
(-89.7 \text { to }-34.3)\end{array}$ \\
\hline \multicolumn{7}{|l|}{ Marital status } \\
\hline \multicolumn{2}{|l|}{$\begin{array}{l}\text { Married/cohabiting } \\
\text { mothers }\end{array}$} & 1 & & & & \\
\hline Single mothers & $\begin{array}{l}55.6 \\
\text { (21.6 to } 89.5)\end{array}$ & $\begin{array}{l}127.9 \\
(92.8163 .0)\end{array}$ & & & & \\
\hline \multicolumn{7}{|l|}{ Delivery } \\
\hline \multicolumn{2}{|l|}{ Vaginal delivery } & 1 & 1 & 1 & 1 & 1 \\
\hline C-section delivery & $\begin{array}{l}118.5 \\
\text { (86.4 to } 150.5)\end{array}$ & $\begin{array}{l}143.2 \\
(108.8 \text { to } 177.5)\end{array}$ & $\begin{array}{l}72.6 \\
(6.8 \text { to } 138.4)\end{array}$ & $\begin{array}{l}84.2 \\
(17.6 \text { to } 150.7)\end{array}$ & $\begin{array}{l}90.8 \\
(49.8 \text { to } 131.8)\end{array}$ & $\begin{array}{l}105.5 \\
\text { (65.2 to } 145.7)\end{array}$ \\
\hline \multicolumn{7}{|l|}{ Parity } \\
\hline Primipara & 1 & 1 & 1 & 1 & 1 & 1 \\
\hline Multipara & $\begin{array}{l}66.5 \\
(34.8 \text { to } 98.2)\end{array}$ & $\begin{array}{l}125.9 \\
(90.5 \text { to } 161.2)\end{array}$ & $\begin{array}{l}47.7 \\
\text { (12.1 to } 83.2)\end{array}$ & $\begin{array}{l}56.7 \\
\text { (15.1 to } 98.2)\end{array}$ & $\begin{array}{l}54.8 \\
\text { (26.7 to } 83.0)\end{array}$ & $\begin{array}{l}65.1 \\
\text { (32.8 to } 97.4)\end{array}$ \\
\hline \multicolumn{7}{|l|}{ Trial arm } \\
\hline Lamivudine arm & 1 & 1 & 1 & 1 & 1 & 1 \\
\hline $\begin{array}{l}\text { Lopinavir/ritonavir } \\
\text { arm }\end{array}$ & $\begin{array}{l}-48.4 \\
(-77.6 \text { to }-19.2)\end{array}$ & $\begin{array}{l}-37.6 \\
(-67.5 \text { to }-7.6)\end{array}$ & $\begin{array}{l}39.9 \\
(12.4 \text { to } 67.4)\end{array}$ & $\begin{array}{l}47.0 \\
(17.9 \text { to } 76.1)\end{array}$ & $\begin{array}{l}22.6 \\
(-0.0 \text { to } 45.2)\end{array}$ & $\begin{array}{l}31.1 \\
\text { (7.1 to } 55.0)\end{array}$ \\
\hline Birth weight (g) & $\begin{array}{l}0.0 \\
(0.0 \text { to } 0.1)\end{array}$ & $\begin{array}{l}0.1 \\
(0.0 \text { to } 0.1)\end{array}$ & $\begin{array}{l}0.0 \\
(0.0 \text { to } 0.1)\end{array}$ & $\begin{array}{l}0.1 \\
(0.0 \text { to } 0.1)\end{array}$ & & \\
\hline
\end{tabular}

BMI, body mass index; EPBF, exclusive or predominant breast feeding.

of infant feeding, and postpartum weight loss. However, C-section delivery was a risk factor for postpartum weight loss ${ }^{28}$ similar to our findings. South Africa had markedly lower rates of vaginal deliveries versus other countries (table 1b). In the year 2000, studies were published demonstrating that elective C-section before the labour and before the rupture of membranes added protection against HIV transmission to the newborn. ${ }^{29} 30$ The lower rates of vaginal deliveries in South Africa were likely due to the country policies (influenced by the scientific 
Table 2d Mothers' HIV-1 disease progression according to EPBF duration adjusted to different covariates: stratification presenting South Africa versus the other sites and pooled analysis

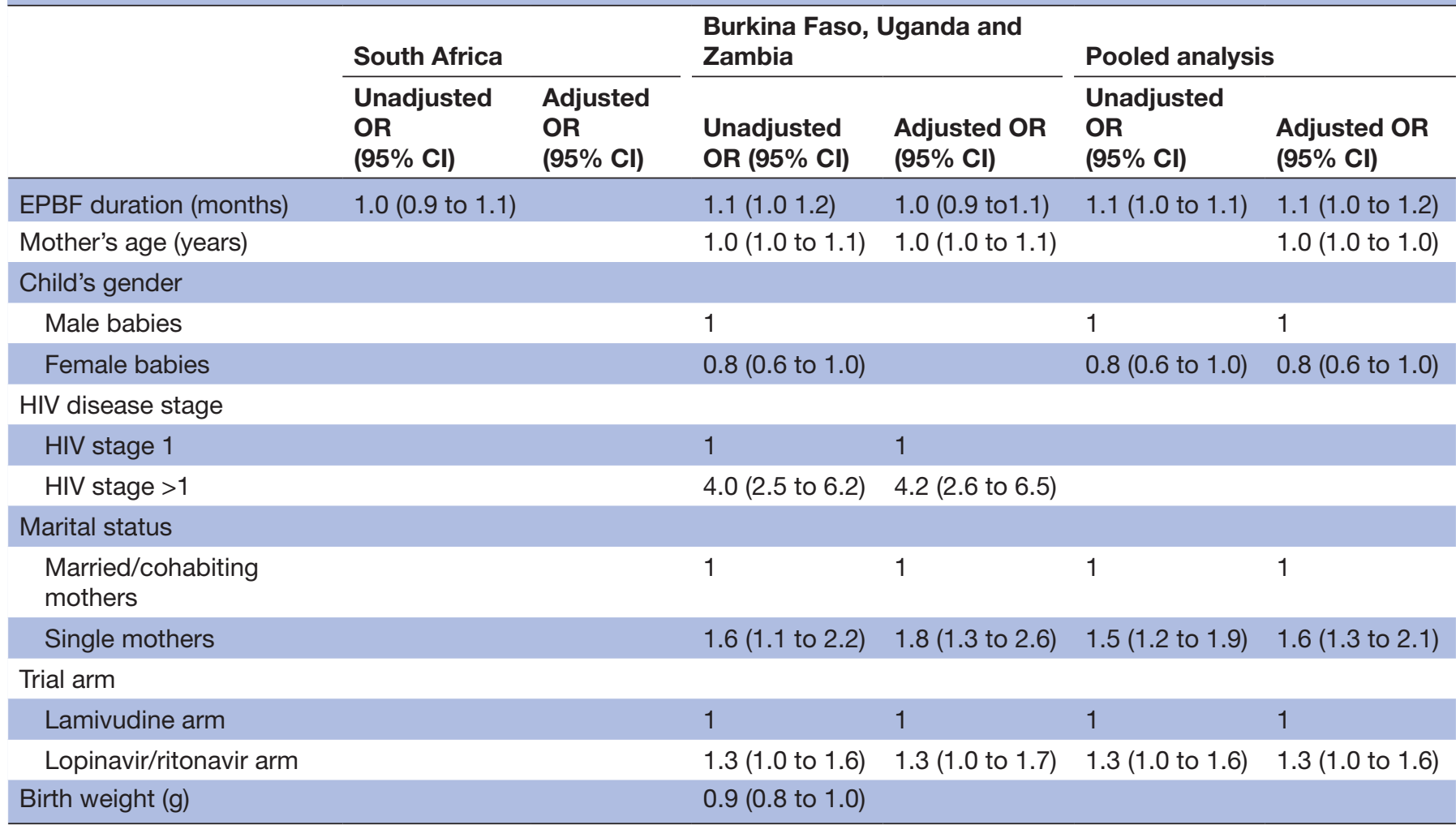

EPBF, exclusive or predominant breast feeding.

evidence) that supported HIV-infected women towards delivering HIV-free babies. This support included free formulas and probably scheduled C-section for the HIV-infected pregnant women and mothers. Why the rest of the countries did not implement the same policy is certainly a matter of affordability and availability of local resources. Another reason is that C-section rate is 'recklessly high' in South Africa where up to $90 \%$ of pregnant women deliver through this method in private hospitals (The Guardian, https://www.theguardian.com/world/2014/sep/24/ caesarean-section-south-africa (accessed on 27 October 2017)). This practice may have spilled over but at a lesser extent into public health facilities. We believe this practice has not skewed our results since these $\mathrm{C}$-section deliveries were not medically indicated at first hand, at least not based on a vaginal delivery risk; therefore, they are not done on women with poorer health status. Actually, South African women had the lowest mean HIV-1 viral load and the highest mean BMI.

Yet, this review of literature ${ }^{28}$ found that less educated mothers $(<12$ years of schooling) were at risk of postpartum weight retention; we found that higher educated women (secondary school or further) were at risk of that weight retention. This difference in our finding may be explained by the difference in our categorisation of the education variable. In our study, less educated participants included only women with primary school level, meaning around 6years of schooling. Therefore, the results of the two studies are not really comparable. A higher education level was also a factor associated with a slower HIV-1 disease progression. This finding is consistent with our result that higher educated women retained more weight.

In a further review of literature on the effects of lactation on the mother's body weight, it is clear that the assumption that the postpartum weight loss is due to the high energy demand associated with lactation has been challenged by many studies. ${ }^{31}$ Some reports conflict with our own findings, such as the one in KwaZulu Natal, where HIV-1-infected mothers at between 8 and 24 weeks had a mean weight loss of $1.4 \mathrm{~kg}$ in contrast to a $0.4 \mathrm{~kg}$ weight gain in HIV-1-uninfected mothers $(\mathrm{P}=0.01)$ during breast feeding. ${ }^{15}$

Regarding the change in CD4 cell count, the South African data support the conclusion that CD4 cell count did not differ significantly between women who breast fed and those who did not. ${ }^{32}$ This finding contradicts the Kenyan study that found that the rate of CD4 cell count decline was higher in breastfeeding than in non-breastfeeding mothers. ${ }^{13}$ However, in that Kenyan study, HIV-1 RNA levels did not differ significantly between breastfeeding and formula-feeding mothers.

Regarding HIV-1 disease progression, the same data showed no deleterious effect of breast feeding in HIV-1-infected mothers, similar to our study findings. The outcome variables were the CD4 and CD8 cell count, the mothers' illness and mortality, and their haemoglobin levels. ${ }^{32}$ Another study from Malawi reached the 
Table 3a Mothers' weight change according to any breastfeeding duration adjusted to different covariates: stratification presenting South Africa versus the other sites and pooled analysis

\begin{tabular}{|c|c|c|c|c|c|c|}
\hline & \multicolumn{2}{|l|}{ South Africa } & \multicolumn{2}{|c|}{$\begin{array}{l}\text { Burkina Faso, Uganda and } \\
\text { Zambia }\end{array}$} & \multicolumn{2}{|c|}{ Pooled analysis } \\
\hline & $\begin{array}{l}\text { Unadjusted } \\
\text { coefficient } \\
(95 \% \mathrm{Cl})\end{array}$ & $\begin{array}{l}\text { Adjusted } \\
\text { coefficient } \\
(95 \% \mathrm{Cl})\end{array}$ & $\begin{array}{l}\text { Unadjusted } \\
\text { coefficient } \\
(95 \% \mathrm{Cl})\end{array}$ & $\begin{array}{l}\text { Adjusted } \\
\text { coefficient } \\
(95 \% \mathrm{Cl})\end{array}$ & $\begin{array}{l}\text { Unadjusted } \\
\text { OR }(95 \% \mathrm{Cl})\end{array}$ & $\begin{array}{l}\text { Adjusted OR } \\
\text { (95\% Cl) }\end{array}$ \\
\hline & & Weight & & & & \\
\hline $\begin{array}{l}\text { Any breastfeeding duration } \\
\text { (months) }\end{array}$ & $\begin{array}{l}0.3 \\
(-0.2 \text { to } 0.8)\end{array}$ & $\begin{array}{l}-0.1 \\
(-0.3 \text { to } 0.0)\end{array}$ & $\begin{array}{l}-0.0 \\
(-0.3 \text { to } 0.2)\end{array}$ & $\begin{array}{l}0.1 \\
(0.0 \text { to } 0.3)\end{array}$ & $\begin{array}{l}-0.0 \\
(-0.3 \text { to } 0.2)\end{array}$ & $\begin{array}{l}-0.0 \\
(-0.2 \text { to } 0.1)\end{array}$ \\
\hline Baseline BMI $\left(\mathrm{kg} / \mathrm{m}^{2}\right)$ & $\begin{array}{l}2.5 \\
(2.4 \text { to } 2.7)\end{array}$ & $\begin{array}{l}2.5 \\
(2.3 \text { to } 2.6)\end{array}$ & $\begin{array}{l}2.5 \\
(2.4 \text { to } 2.6)\end{array}$ & $\begin{array}{l}2.4 \\
(2.3 \text { to } 2.5)\end{array}$ & $\begin{array}{l}2.5 \\
(2.4 \text { to } 2.6)\end{array}$ & $\begin{array}{l}2.4 \\
(2.3 \text { to } 2.5)\end{array}$ \\
\hline Mothers' age (years) & $\begin{array}{l}0.8 \\
(0.5 \text { to } 1.2)\end{array}$ & $\begin{array}{l}0.2 \\
(0.0 \text { to } 0.3)\end{array}$ & $\begin{array}{l}0.5 \\
(0.4 \text { to } 0.6)\end{array}$ & $\begin{array}{l}0.1 \\
(0.1 \text { to } 0.2)\end{array}$ & $\begin{array}{l}0.5 \\
(0.40 .7)\end{array}$ & $\begin{array}{l}0.1 \\
(0.1 \text { to } 0.2)\end{array}$ \\
\hline \multicolumn{7}{|l|}{ HIV disease stage } \\
\hline HIV stage 1 & 1 & 1 & 1 & & & \\
\hline HIV stage $>1$ & $\begin{array}{l}12.4 \\
(-4.5 \text { to } 29.4)\end{array}$ & $\begin{array}{l}6.4 \\
(0.0 \text { to } 12.7)\end{array}$ & $\begin{array}{l}-2.8 \\
(-6.4 \text { to } 0.8)\end{array}$ & & & \\
\hline \multicolumn{7}{|l|}{ Education } \\
\hline Did not complete primary school & & & 1 & 1 & 1 & 1 \\
\hline Completed primary school & & & $\begin{array}{l}3.9 \\
(2.0 \text { to } 5.9)\end{array}$ & $\begin{array}{l}0.3 \\
(-0.6 \text { to } 1.1)\end{array}$ & $\begin{array}{l}4.4 \\
(2.2 \text { to } 6.5)\end{array}$ & $\begin{array}{l}0.6 \\
(-0.3 \text { to } 1.5)\end{array}$ \\
\hline Secondary school and further & & & $\begin{array}{l}2.7 \\
(1.2 \text { to } 4.1)\end{array}$ & $\begin{array}{l}0.9 \\
(0.2 \text { to } 1.5)\end{array}$ & $\begin{array}{l}3.1 \\
\text { (1.5 to } 4.6)\end{array}$ & $\begin{array}{l}1.0 \\
(0.4 \text { to } 1.7)\end{array}$ \\
\hline \multicolumn{7}{|l|}{ Marital status } \\
\hline Married/cohabiting mothers & 1 & & & & 1 & \\
\hline Single mothers & $\begin{array}{l}-3.1 \\
(-7.2 \text { to } 0.9)\end{array}$ & & & & $\begin{array}{l}-1.2 \\
(-3.0 \text { to } 0.5)\end{array}$ & \\
\hline \multicolumn{7}{|l|}{ Delivery } \\
\hline Vaginal delivery & & & 1 & & 1 & \\
\hline C-section delivery & $\begin{array}{l}3.7 \\
(-0.4 \text { to } 7.9)\end{array}$ & $\begin{array}{l}-1.6 \\
(-3.2 \text { to } 0.0)\end{array}$ & $\begin{array}{l}4.5 \\
(1.5 \text { to } 7.6)\end{array}$ & & $\begin{array}{l}4.4 \\
\text { (2.1 to } 6.7)\end{array}$ & $\begin{array}{l}-1.2 \\
(-2.1 \text { to }-0.2)\end{array}$ \\
\hline \multicolumn{7}{|l|}{ Parity } \\
\hline Primipara & 1 & 1 & 1 & 1 & 1 & \\
\hline Multipara & $\begin{array}{l}6.1 \\
(1.9 \text { to } 10.3)\end{array}$ & & $\begin{array}{l}3.1 \\
\text { (1.4 to } 4.7)\end{array}$ & & $\begin{array}{l}3.9 \\
(2.3 \text { to } 5.4)\end{array}$ & \\
\hline \multicolumn{7}{|l|}{ Trial arm } \\
\hline Lamivudine arm & 1 & 1 & 1 & 1 & 1 & \\
\hline Lopinavir/ritonavir arm & $\begin{array}{l}2.0 \\
(-2.0 \text { to } 6.1)\end{array}$ & $\begin{array}{l}0.7 \\
(-0.8 \text { to } 2.2)\end{array}$ & $\begin{array}{l}-0.1 \\
(-1.4 \text { to } 1.3)\end{array}$ & $\begin{array}{l}-0.3 \\
(-0.9 \text { to } 0.3)\end{array}$ & $\begin{array}{l}0.3 \\
(-1.0 \text { to } 1.6)\end{array}$ & $\begin{array}{l}0.1 \\
(-0.7 \text { to } 0.4)\end{array}$ \\
\hline
\end{tabular}

BMI, body mass index.

same conclusion that breast feeding was not associated with higher risk of maternal morbidity or mortality. ${ }^{33} \mathrm{~A}$ study in Zambia concluded in the same direction that at 12 months after delivery, there was no difference in mortality between women who breast fed for a short duration (4 months) versus those who breast fed for a duration of their own choice. ${ }^{17}$ An individual patient data meta-analysis on mortality among HIV-1-infected mothers according to children's feeding modality confirmed that the risk of dying within 18 months post partum was not significantly affected by the infants' feeding modality (ie, ever vs never breast fed). ${ }^{34}$

In healthy breastfeeding mothers, the postpartum weight loss would be around $0.5 \mathrm{~kg}$ per month among population with relatively high mean of BMI. The mechanism of the weight loss would be burning of 483-538 kcal per day. ${ }^{35} 36$ Therefore, losing weight after birth is likely when the mother's calorie intake does not cover the calorie expense related to breast-milk production. Considering these findings, we think that energy 
Table 3b Mothers' CD4 cell count change according to any breastfeeding duration adjusted to different covariates: stratification presenting South Africa versus the other sites and pooled analysis

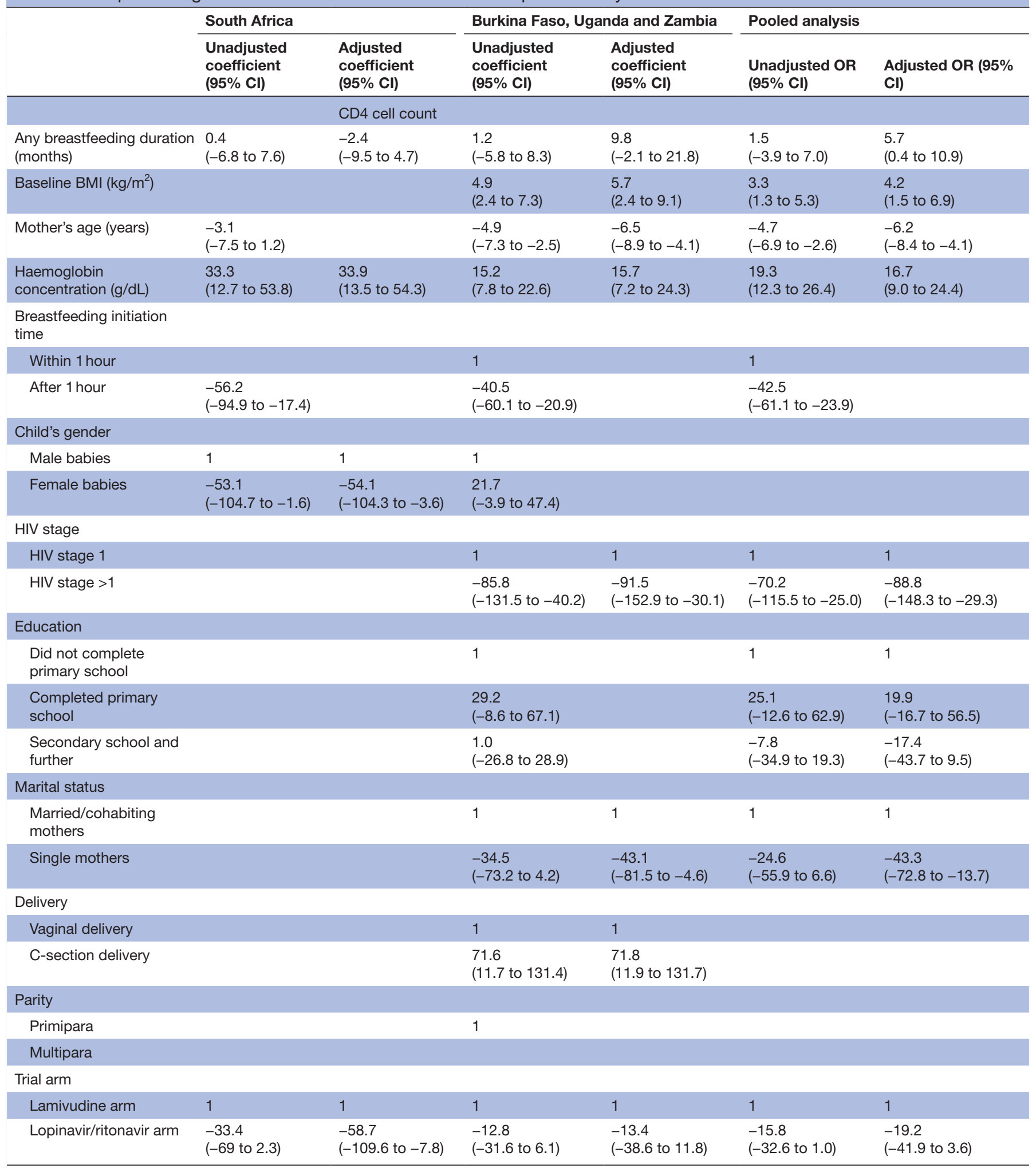

BMI, body mass index.

requirement and thus the metabolic stress related to breast feeding would be quite bearable. This may explain why in our study HIV-1-infected, immune-competent and breastfeeding mothers' health status was not deteriorated by breast feeding. This evidence inspires the idea that option A peri-exposure antiretroviral prophylaxis might still have pertinent indications since breast feeding remained the most frequent feeding 
Table 3c Mothers' HIV-1 viral load change according to any breastfeeding duration adjusted to different covariates: stratification presenting South Africa versus the other sites and pooled analysis

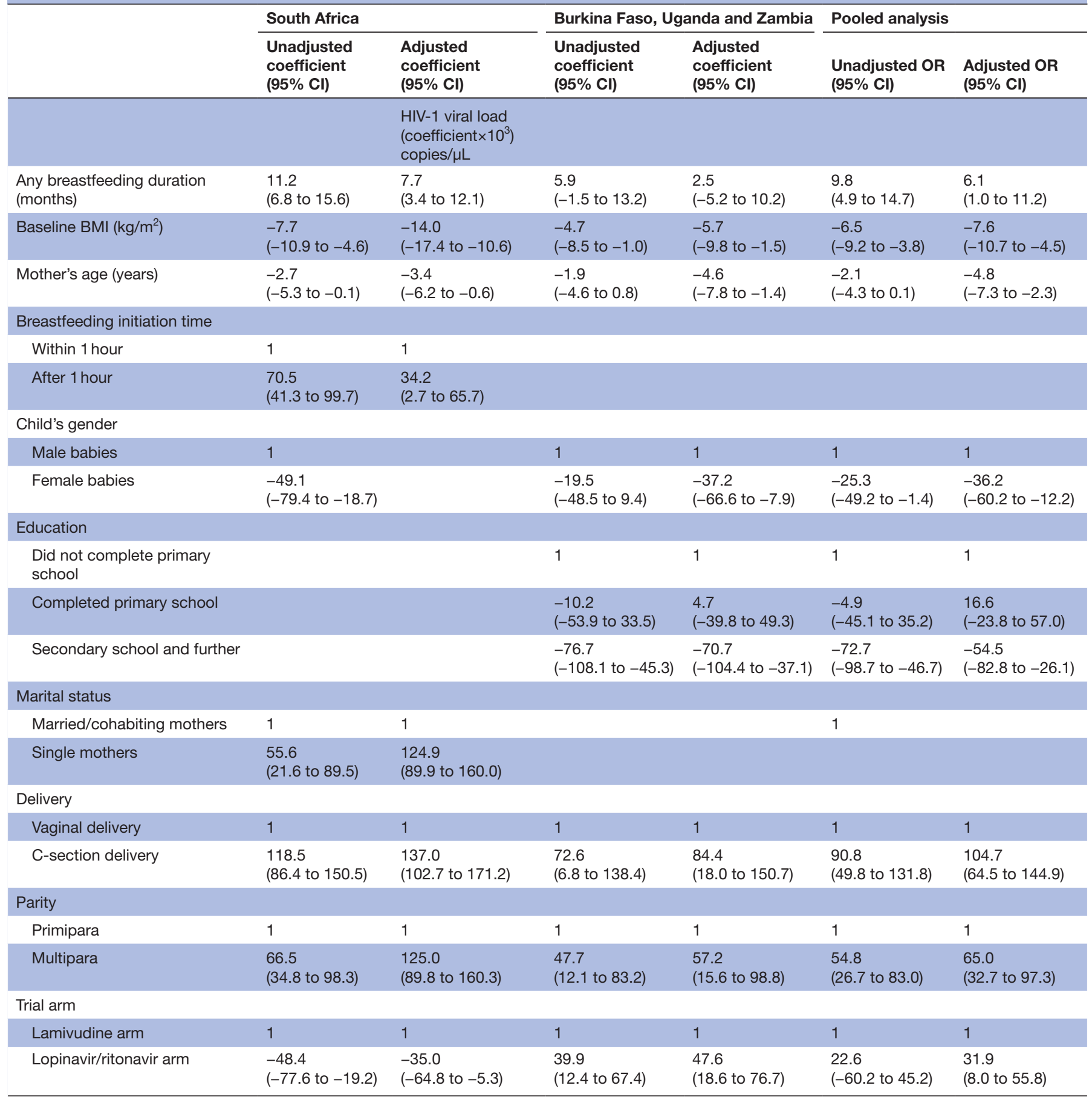

BMI, body mass index.

option in sub-Saharan Africa and since breast milk might still host HIV-1 reservoirs that mothers' prophylaxis could not always $100 \%$ suppress. ${ }^{37}$

\section{Strengths and limitations}

Our study has been implemented in four countries in Africa, including Burkina Faso (West), South Africa and Zambia (South) and Uganda (East). Therefore, we consider our study population representative of the sub-Sahara African population. The data were also collected in the rigorous context of a clinical trial, which minimised the loss to follow-up, the missing data as well as other data collection errors, and therefore improved the quality of our data.

However, the selection associated with the environment of a clinical trial-usually quite different from a routine environment-may have biased our findings. Nonetheless, our endpoints (mother's weight, CD4 cell count and HIV-1 viral load) were sufficiently robust for us to vouch for their validity. Another point of note is the stratification of the participants into two strata, that is, South Africa versus Burkina Faso, Uganda and Zambia. This stratification reduced the sample size in South Africa. Thus, some 
Table 3d Mothers' HIV-1 disease progression according to any breastfeeding duration adjusted to different covariates: stratification presenting South Africa versus the other sites and pooled analysis

\begin{tabular}{|c|c|c|c|c|c|c|}
\hline & \multicolumn{2}{|l|}{ South Africa } & \multicolumn{2}{|c|}{$\begin{array}{l}\text { Burkina Faso, Uganda and } \\
\text { Zambia }\end{array}$} & \multicolumn{2}{|l|}{ Pooled analysis } \\
\hline & $\begin{array}{l}\text { Unadjusted } \\
\text { OR } \\
(95 \% \mathrm{Cl})\end{array}$ & $\begin{array}{l}\text { Adjusted OR } \\
(95 \% \mathrm{Cl})\end{array}$ & $\begin{array}{l}\text { Unadjusted } \\
\text { OR } \\
(95 \% \mathrm{Cl})\end{array}$ & $\begin{array}{l}\text { Adjusted OR } \\
(95 \% \mathrm{Cl})\end{array}$ & $\begin{array}{l}\text { Unadjusted OR } \\
(95 \% \mathrm{Cl})\end{array}$ & $\begin{array}{l}\text { Adjusted OR } \\
(95 \% \mathrm{Cl})\end{array}$ \\
\hline & & $\begin{array}{l}\text { HIV disease } \\
\text { progress }\end{array}$ & & & & \\
\hline $\begin{array}{l}\text { Any breastfeeding duration } \\
\text { (months) }\end{array}$ & & & 1.1 (1.0 to 1.2$)$ & $1.0(0.9$ to 1.1$)$ & $1.0(0.9$ to 1.0$)$ & $1.0(0.9$ to 1.0$)$ \\
\hline Baseline BMI $\left(\mathrm{kg} / \mathrm{m}^{2}\right)$ & & & $1.0(1.0$ to 1.1$)$ & & & \\
\hline Mother's age (years) & & & & $1.0(1.0$ to 1.1$)$ & $1.0(0.9$ to 1.0$)$ & \\
\hline \multicolumn{7}{|l|}{ Breastfeeding initiation time } \\
\hline Within 1 hour & 1 & & & & & \\
\hline \multicolumn{7}{|l|}{ After 1 hour } \\
\hline \multicolumn{7}{|l|}{ Child's gender } \\
\hline Male babies & & & 1 & & 1 & \\
\hline Female babies & & & 0.8 (0.6 to 1.0$)$ & & 0.8 (0.6 to 1.0$)$ & \\
\hline \multicolumn{7}{|l|}{ HIV stage } \\
\hline HIV stage 1 & & & 1 & 1 & 1 & 1 \\
\hline HIV stage $>1$ & & & 4.0 (2.5 to 6.2$)$ & 4.2 (2.6 to 6.6$)$ & 4.4 (2.8 to 6.7$)$ & 4.6 (2.9 to 7.3$)$ \\
\hline \multicolumn{7}{|l|}{ Education } \\
\hline $\begin{array}{l}\text { Did not complete primary } \\
\text { school }\end{array}$ & & & 1 & & & 1 \\
\hline Completed primary school & & & & & & $1.4(0.9$ to 2.0$)$ \\
\hline $\begin{array}{l}\text { Secondary school and } \\
\text { further }\end{array}$ & & & & & & $0.7(0.5$ to 0.9$)$ \\
\hline \multicolumn{7}{|l|}{ Marital status } \\
\hline $\begin{array}{l}\text { Married/cohabiting } \\
\text { mothers }\end{array}$ & & & 1 & 1 & & \\
\hline Single mothers & & & 1.6 (1.1 to 2.2$)$ & 1.8 (1.2 to 2.6$)$ & 1.5 (1.2 to 1.9$)$ & \\
\hline \multicolumn{7}{|l|}{ Trial arm } \\
\hline Lamivudine arm & & & 1 & 1 & 1 & 1 \\
\hline Lopinavir/ritonavir arm & & & 1.3 (1.0 to 1.6$)$ & $1.3(1.0$ to 1.7$)$ & 1.3 (1.0 to 1.6$)$ & $1.3(1.0$ to 1.6$)$ \\
\hline
\end{tabular}

BMI, body mass index.

of the modelling for South Africa could be less rigorous, and the findings regarding the risk factors there may not truly reflect the reality.

\section{CONCLUSION}

Breast feeding, whatever the type (exclusive or any) as far as this study can conclude, was not a risk factor for the HIV-1-infected mothers' weight, CD4 cell count and HIV-1 viral load change, or HIV-1 disease progression, keeping in mind that all the participants had a baseline CD4 cell count $>350$ cells $/ \mu \mathrm{L}$. The mothers' baseline high weight and high haemoglobin concentration were important factors in being consistently associated with an improvement of the outcome variables at stake. A higher education level was also a factor associated with a slower HIV-1 disease progression. Considering the benefits of breast milk for infants, and the consensus results from different studies elsewhere that breast feeding does not harm HIV-1-infected mothers, this study also supports the WHO 2016 guidelines on infant feeding, which indicate that mothers living with HIV should breast feed for at least 12 months and up to 24 months, provided that the right treatment or prophylaxis for the infection is given where formula feeding is unsafe. ${ }^{12}$

\section{Author affiliations}

${ }^{1}$ Centre for International Health, University of Bergen, Bergen, Norway

${ }^{2}$ National Health Research Institute, Centre National pour la Recherche Scientifique et Technologique, Ouagadougou, Burkina Faso

${ }^{3}$ Pathogenesis and Control of Chronic Infections, Université Montpellier, INSERM, Etablissement francais du sang (EFS), CHU Montpellier, Montpellier, France ${ }^{4}$ Faculty of Health Sciences, Centre de Recherche International en Santé (CRIS), University of Ouagadougou, Ouagadougou, Burkina Faso 
${ }^{5}$ Department of Paediatrics and Child Health, School of Medicine, University of Zambia, Lusaka, Zambia

${ }^{6}$ University Teaching Hospital, Lusaka, Zambia

${ }^{7}$ Department of Paediatrics and Child Health, School of Medicine, College of Health Sciences, Makerere University, Kampala, Uganda

${ }^{8}$ Effective Care Research Unit, University of Fort Hare, Alice, South Africa

Acknowledgements We would like to thank all the mothers who agreed to be part of the trial together with their children. Our acknowledgements also go to the different ANRS 12174 site staff for their dedicated effort in this research. We are also very grateful to the University of Bergen and the Centre for International Health for providing the infrastructure, and the needed supervision and training. We also thank the UMR 1058, pathogenesis and control of chronic infections, Montpellier, France, from which we received invaluable support regarding data management. The final typescript has been improved through the help of BioMedES Ltd, UK (http://www.biomedes.co.uk).

Contributors Conceptualisation: ENS, IMSE, NN, NYM, PVdP, TT. Data curation: ENS, RV. Formal analysis: ENS, IMSE. Investigation: ENS, MS-M, NYM, JKT, CK, GJH. Methodology: ENS, IMSE, TT. Project administration: NN, PVdP, TT, NYM. Resources: TT, IMSE. Supervision: TT, IMSE, NYM, NN. Validation: TT, IMSE, NYM, NN. Writing the original draft: ENS, IMSE. Writing and review and editing: ENS, IMSE, NN, NYM, TT, RV, CK, JKT, GJH, MS-M, KH.

Funding This study used data collected in the context of the ANRS 12174 clinical trial funded by the French National Institute of Health and Medical ResearchNational Agency for Research on AIDS and Viral Hepatitis (INSERM-ANRS), the European and Developing Countries Clinical Trials Partnership (EDCTP; grant no. CT.2006.33020.004), the Research Council of Norway (GlobVac grant no. 183600) and the Total Foundation. ENS benefited from a PhD grant from the Norwegian Quota Scheme.

Disclaimer The funders had no role in study design, data collection and analysis, decision to publish or preparation of the manuscript.

Competing interests None declared.

Patient consent Not required.

Ethics approval The Ethical Committee for Health Research in Burkina Faso (EC no. 2008-039), the Biomedical Research Ethics Committee in Zambia (EC no. 008-02-08), the Uganda National Council for Science and Technology (EC no. HS470), the Stellenbosch University ethical committees, the Medicines Control Council in South Africa (EC no. 20090938) and the Regional Committee for Medical Research Ethics of Norway.

Provenance and peer review Not commissioned; externally peer reviewed.

Data sharing statement The study sponsor (the French agency for research on HIV and viral hepatitis: ANRS) offers data sharing upon request. ANRS will be the contact organisation (direction@anrs.fr). The shared data will be those presented in the article.

Open Access This is an Open Access article distributed in accordance with the Creative Commons Attribution Non Commercial (CC BY-NC 4.0) license, which permits others to distribute, remix, adapt, build upon this work non-commercially, and license their derivative works on different terms, provided the original work is properly cited and the use is non-commercial. See: http://creativecommons.org/ licenses/by-nc/4.0/

(c) Article author(s) (or their employer(s) unless otherwise stated in the text of the article) 2018. All rights reserved. No commercial use is permitted unless otherwise expressly granted.

\section{REFERENCES}

1. UNAIDS. Core epidemiology. 2015 http://www.unaids.org/en/res ources/documents/2015/20150714_coreepidemiologyslides_ppt; (accessed 11 Nov 2015).

2. UNAIDS. Global AIDS update 2016. http://www.unaids.org/en/ resources/documents/2016/Global-AIDS-update-2016 (accessed 17 Oct 2016).

3. Eaton JW, Rehle TM, Jooste S, et al. Recent HIV prevalence trends among pregnant women and all women in sub-Saharan Africa: implications for HIV estimates. AIDS 2014;28(suppl 4):8.

4. Younas M, Psomas C, Reynes J, et al. Immune activation in the course of HIV-1 infection: causes, phenotypes and persistence under therapy. HIV Med 2016;17:89-105.
5. Jacob JA. Men with HIV age faster according to DNA methylation study. JAMA 2016;316:135

6. Zevin AS, McKinnon L, Burgener A, et al. Microbial translocation and microbiome dysbiosis in HIV-associated immune activation. Curr Opin HIV AIDS 2016;11:182-90.

7. DeVaughn S, Müller-Oehring EM, Markey B, et al. Aging with HIV-1 Infection: motor functions, cognition, and attention-a comparison with Parkinson's disease. Neuropsychol Rev 2015;25:424-38.

8. World Health Organization. Antiretroviral therapy for HIV infection in adults and adolescents: recommendations for a public health approach [2006 revision]134: World Health Organization, 2006.

9. Koyanagi A, Humphrey JH, Moulton LH, et al. Predictive value of weight loss on mortality of HIV-positive mothers in a prolonged breastfeeding setting. AIDS Res Hum Retroviruses 2011;27:1141-8.

10. Zaba B, Calvert C, Marston M, et al. Effect of HIV infection on pregnancy-related mortality in sub-Saharan Africa: secondary analyses of pooled community-based data from the network for Analysing Longitudinal Population-based HIV/AIDS data on Africa (ALPHA). Lancet 2013;381:1763-71.

11. Guttmacher Institute. HIV linked to many pregnancy-related deaths in sub-Saharan Africa. International perspective on sexual and reproductive health 2013;39:4.

12. World Health Organization, United Nations Children's Fund. Guideline: updates on HIV and infant feeding: the duration of breastfeeding, and support from health services to improve feeding practices among mothers living with HIV. Geneva: World Health Organization, 2016.

13. Otieno PA, Brown ER, Mbori-Ngacha DA, et al. HIV-1 disease progression in breast-feeding and formula-feeding mothers: a prospective 2-year comparison of T cell subsets, HIV-1 RNA levels, and mortality. J Infect Dis 2007;195:220-9.

14. Nduati R, Richardson BA, John G, et al. Effect of breastfeeding on mortality among HIV-1 infected women: a randomised trial. Lancet 2001;357:1651-5.

15. Papathakis PC, Van Loan MD, Rollins NC, et al. Body composition changes during lactation in HIV-infected and HIV-uninfected South African women. J Acquir Immune Defic Syndr 2006;43:467-74.

16. Sedgh G, Spiegelman D, Larsen U, et al. Breastfeeding and maternal HIV-1 disease progression and mortality. AIDS 2004;18:1043-9.

17. Kuhn L, Kasonde P, Sinkala M, et al. Prolonged breast-feeding and mortality up to two years post-partum among HIV-positive women in Zambia. AIDS 2005;19:1677-81.

18. Winkvist A, Rasmussen KM, Lissner L. Associations between reproduction and maternal body weight: examining the component parts of a full reproductive cycle. Eur J Clin Nutr 2003;57:114-27.

19. Murnane PM, Arpadi SM, Sinkala M, et al. Lactation-associated postpartum weight changes among HIV-infected women in Zambia. Int J Epidemiol 2010;39:1299-310.

20. Ladner J, Castetbon K, Leroy V, et al. Pregnancy, body weight and human immunodeficiency virus infection in African women: a prospective cohort study in Kigali (Rwanda), 1992-1994. Pregnancy and HIV Study Group (EGE). Int J Epidemiol 1998;27:1072-7.

21. Hartmann PE, Sherriff JL, Mitoulas LR. Homeostatic mechanisms that regulate lactation during energetic stress. J Nutr 1998;128:394S-9.

22. Somé $\mathrm{E}$, Engebretsen I, Nagot $\mathrm{N}$, et al. R BreastfeedingandBMI Main_ENSOME_WithoutTrackChange.pdf. PloS One 2017.

23. Nagot N, Kankasa C, Meda N, et al. Lopinavir/ritonavir versus Lamivudine peri-exposure prophylaxis to prevent HIV-1 transmission by breastfeeding: the PROMISE-PEP trial Protocol ANRS 12174. BMC Infect Dis 2012;12:246.

24. Nagot N, Kankasa C, Tumwine JK, et al. Extended pre-exposure prophylaxis with lopinavir-ritonavir versus lamivudine to prevent HIV-1 transmission through breastfeeding up to 50 weeks in infants in Africa (ANRS 12174): a randomised controlled trial. Lancet 2016;387:566-73.

25. ANRS. ANRS scale to grade the severity of adverse events in adults; version $n^{\circ} 1.04$ November 2008. file:///C:/Users/install/Downloads/ ANRS-GradeEI-V1-En-2008.pdf (accessed 14 Jan 2016).

26. Becquet R, Bland R, Leroy V, et al. Duration, pattern of breastfeeding and postnatal transmission of HIV: pooled analysis of individual data from West and South African cohorts. PLoS One 2009;4:e7397.

27. Somé EN, Engebretsen IMS, Nagot N, et al. Breastfeeding patterns and its determinants among mothers living with Human Immunodeficiency Virus-1 in four African countries participating in the ANRS 12174 trial. Int Breastfeed J 2016;12.

28. Crowell DT. Weight change in the postpartum period. A review of the literature. J Nurse Midwifery 1995;40:418-23.

29. Maguire A, Sánchez E, Fortuny C, et al. Potential risk factors for vertical HIV-1 transmission in Catalonia, Spain: the protective role of 
cesarean section. The Working Group on HIV-1 Vertical Transmission in Catalonia. AIDS 1997;11:1851-7.

30. Kind C, Rudin C, Siegrist CA, et al. Prevention of vertical HIV transmission: additive protective effect of elective Cesarean section and zidovudine prophylaxis. Swiss Neonatal HIV Study Group. AIDS 1998;12:205-10.

31. Rogers IS, Golding J, Emmett PM. The effects of lactation on the mother. Early Hum Dev 1997;49:S191-S203.

32. Coutsoudis A, Coovadia H, Pillay K, et al. Are HIV-infected women who breastfeed at increased risk of mortality? AIDS 2001;15:653-5.

33. Taha TE, Kumwenda NI, Hoover DR, et al. The impact of breastfeeding on the health of HIV-positive mothers and their children in sub-Saharan Africa. Bull World Health Organ 2006;84:546-54.

34. Breastfeeding and HIV International Transmission Study Group. Mortality among HIV-1-infected women according to children's feeding modality: an individual patient data meta-analysis. J Acquir Immune Defic Syndr 2005;39:9.

35. Trumbo P, Schlicker S, Yates AA, et al. Dietary reference intakes for energy, carbohydrate, fiber, fat, fatty acids, cholesterol, protein and amino acids. J Am Diet Assoc 2002;102:1621-30.

36. Lovelady C. Balancing exercise and food intake with lactation to promote post-partum weight loss. Proc Nutr Soc 2011;70:181-4.

37. Van de Perre P, Rubbo PA, Viljoen J, et al. HIV-1 reservoirs in breast milk and challenges to elimination of breast-feeding transmission of HIV-1. Sci Transl Med 2012;4:143sr3. 